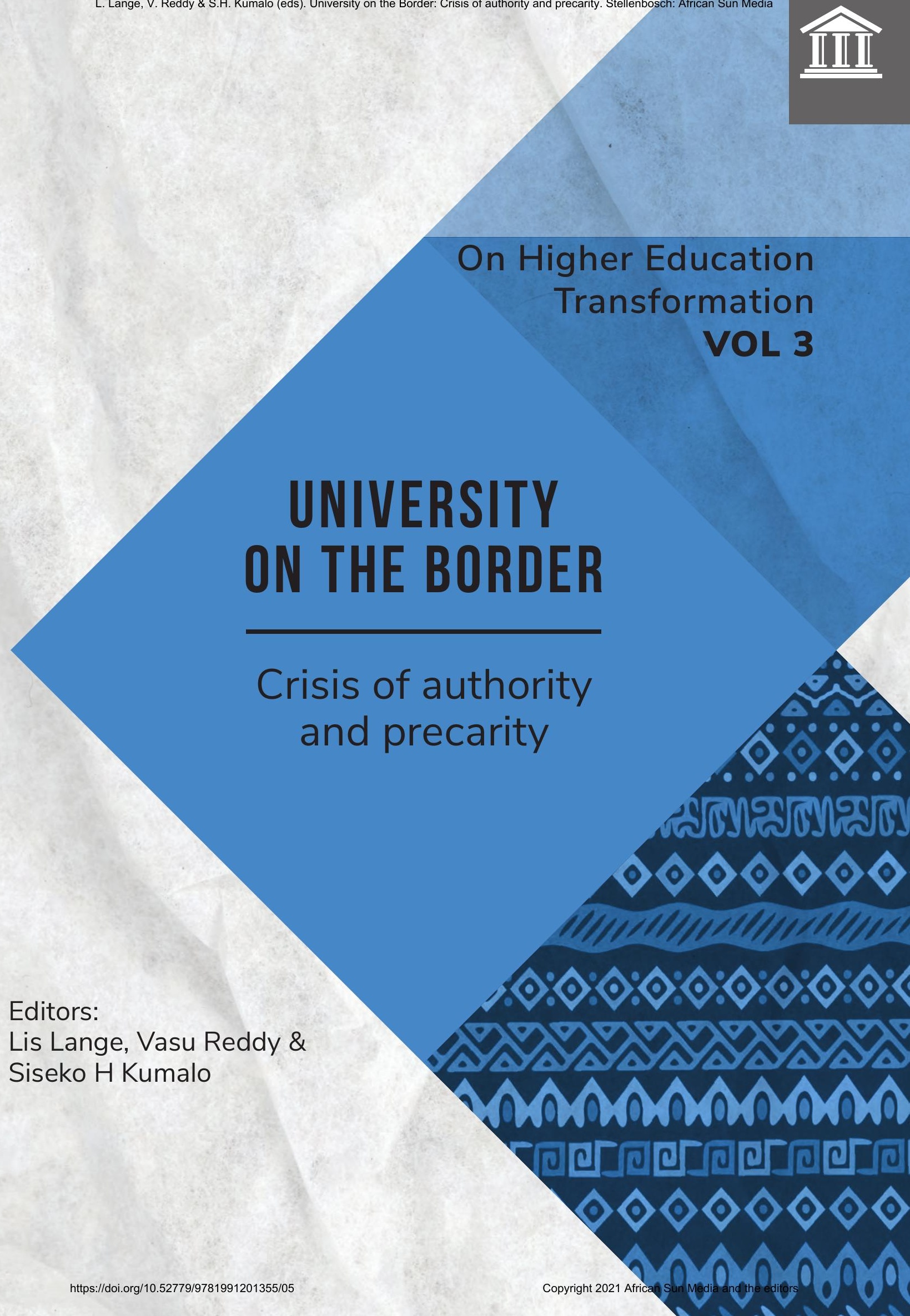




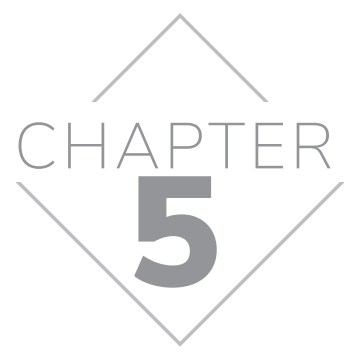

\title{
Décolonisation Destituante
}

\author{
Ulrike Kistner
}

\section{INTRODUCTION}

After a sojourn in Martinique, where he taught at the Schoelcher School, Octave Mannoni lived and worked in Madagascar between 1925 and 1945 in various positions, including a teaching position in Philosophy, the position of head of the colonial information service (from which he was dismissed by De Gaulle), and a position in the French Ministry of War. Between 1944 and 1947, in the course of the intensifying struggle that became known as the "Malagasy Uprising”, Mannoni wrote his study on The Psychology of Colonisation.

Returning to Madagascar after the Malagasy Uprising had been violently crushed, Mannoni composed the Afterword to his book. Back in France in 1948, Mannoni went into analysis, and training analysis, with Jacques Lacan, to then become a practising analyst himself. His stance was marked by a 'return to Freud' independently of Lacan's.

Mannoni's manuscript was first published under the title Psychologie de la colonisation in 1950, and first appeared in English translation under the title Prospero and Caliban. The Psychology of Colonization in 1956.

The book came under heavy fire from Frantz Fanon (1952) and Aimé Césaire (1955), primarily for its construal of a pre-colonial psychic substratum, and 


\section{UNIVERSITY ON THE BORDER}

a 'dependency complex' attributed to the Malagasy in the context of the colonial encounter. It is this critique that has directed readings of Mannoni's Psychology of Colonization ever since.

Approximately twenty years after composing the manuscript, editors of the London-based journal, Race (later Race \& Class) prompted Mannoni to re-assess his work. The short article written in response was published under the title 'The Decolonisation of Myself' (in French and in English) in the journal in 1966. It has received much less attention than the book, being cast by critics in an apologetic light that obscures the article's own tenets. Reading this article as an unapologetic autocritique, I would argue here, can yield insights relevant to current discussions on decoloniality.

In the following, I would like to contextualise Mannoni's project in terms of the contestations it ignited in historical contexts of colonialism, anti-colonial resistance, and decolonisation. More pertinently for present purposes, I would like to trace the critical move indicated in Mannoni's re-assessment of his work, from colonially structured social relations implicating race and racism commonly understood as a 'social problem', to an 'epistemological problematic' fundamental to a philosophical critique. It is the latter aim that would pose the task of conceptual labour.

\section{MANNONI'S SELF-ASSESSMENT}

Mannoni's self-assessment published in 1966 under the title 'The Decolonisation of Myself' comes with considerable hindsight, reflecting on the previous work published in English in 1956 under the title Prospero and Caliban. The Psychology of Colonization. His self-assessment takes account of the role of the book in the debates on colonisation and anti-colonial resistance, spanning geopolitical topoi across Martinique, Algeria, and Madagascar. At the same time, the self-assessment tracks, from the perspective of a trained psychoanalyst, the attempt embarked on in the earlier work: that of providing a psychological account of the psycho-social reconfigurations in the colonial encounter. Thus, for a "psychology of colonisation", the earlier book and the later autocritique would have to be read in tandem. Considered in this dialogical relation, the project appears immediately as a "psychology of 
decoloninisation"1 (as Mannoni would have it in the 'Author's Note' to the Second Edition of 1964), involving a deconstructive autocritique - 'The Decolonisation of Myself'.

The distance between the first version of the book and the self-assessment approximately twenty years later is mediated by the prefaces to each of the subsequent editions of the book. While avowing the "weaknesses of the book" (1956), particularly with respect to the "inadequacy of psychological concepts" (1964), Mannoni insists on preserving fidelity to the historicity of the formation of ideas and concepts, rather than attempting to change it in line with later historical insights, even as the colonial order of the time that gave rise to an attempt to write a 'psychology of colonisation' had been superseded (1990 [1956]:6).

With the hindsight articulated in the 1964 edition, Mannoni hypothetically invokes Freud's advice. The relevant passage from Freud's letter to his friend Oskar Pfister of 16 August 1909 reads:

[G]et the work done straight away and do not wait for years before finishing it. Happy is the wooing that's not long in the doing, so to speak. Only while the first impulse lasts will you be able to do the work with so much freshness and vigour. If you go on working, in a few years' time you will see things differently and more correctly, you will put individual problems in the foreground and suspect deeper connections.

(1963 [1909]:27)

This advice resonates in Mannoni's 1966 autocritique taking account of the changed configurations since Independence; a different book would have had to be written, which would more appropriately be focused on the 'psychology of decolonisation' (1966:327). But, Mannoni avers, it is not "simply a matter of taking new situations into account” (1966:327). What immediately impinges is the non-synchronicity between the psychological/philosophical and historical events: ideas and psychological registrations do not change in the same way in which historical configurations change (Mannoni, 1966:328).

1 Mannoni is at pains to point out that this would not require a second volume or a sequel to his earlier book: "'the psychology of colonisation' remains integral to 'the psychology of decolonisation', imposing the task of examining 'how the ghost of the former colonial subject haunts [...] relationships among whites who have never left Europe [...]” (Mannoni, 1966:330). 


\section{UNIVERSITY ON THE BORDER}

But more importantly, the fulcrum of the contestations around the "dependency complex" attributed to the colonised is taken up by the question of "what the significance was of an attempt to find a purely psychological explanation for the problems and difficulties arising from colonisation" (Mannoni, 1966:328). Here Mannoni responds to his early critics, foremost amongst them Fanon (1986 [1952]) and Césaire (1955), with whom he had been in contact during his years in Martinique.

Fanon had concurred with Mannoni that colonialism produced new configurations spawning "a mass of illusions and misunderstandings that only psychological analysis can place and define” (Fanon, 1986 [1952]:85; Mannoni, 1990 [1956]:17, 185); but he had challenged Mannoni's culturalistic construal of a dependency complex for the colonised, which antedates colonisation (Fanon, 1986 [1952]:85). Other critics have pointed more generally to the limitations of a psychoanalytic account of colonisation, in the face of the violence of colonial impositions, and the economic interests driving them. ${ }^{2}$

Mannoni counters the latter group of critics by showing the limitations of a narrow economic approach to the study of colonisation. "What keeps the real colonial tied to the colonial situation ... is not primarily profit", but the psychological satisfactions granted by the pleasure of acting from the position of the master (Mannoni, 1990 [1956]:200, 204), racially and paternalistically shored up. The assertion of racial superiority offers compensation for a sense of personal inferiority (Mannoni, 1990 [1956]:121). For that reason,

it is not enough to denounce the colonial situation as one of economic exploitation - which of course it is. One must also be willing to examine [...] the way economic inequality is expressed, how [...] it is embodied in struggles for prestige, in alienation, in bargaining positions and debts of gratitude, and in the invention of new myths and the creation of new personality types.

(Mannoni, 1990 [1964]:8)

On this approach, too, Fanon would broadly agree, as attested to by his chapter on 'The Negro and Psychopathology' in Black Skin, White Masks. However, in contrast to Fanon, whose explanations of colonial pathogeny turn on defensive reactions and projections in the context of oppression and cultural impositions, Mannoni's book takes its cues from some concepts and tenets 
of Alfred Adler's personality theory. ${ }^{3}$ In particular, it takes up the notions of inferiority and dependency for the construal of a guilt-ridden inferiority complex and its compensation in the case of Western European colonialists, on the one hand, and a dependency complex enjoined by hierarchical social structures including the cult of the dead in the case of the colonised, on the other hand. For Mannoni, dependency is not initially or primarily a matter of racialised subordination, but of a socio-cultural-psychic structuration historically typified in feudalism. The social divisions opening up in the colonial encounter are attributed by Mannoni to colonial modernity, with the political-social-cultural-psychic injunction for the subject to become independent from parental and primary group ties (while incurring guilt in the process), imposed on a pre-colonial feudal subject interpellated in a sociocultural-psychically integral form of dependency, which tends to become a 'complex' only through its dislodging in the colonial encounter.

For Fanon, on the other hand, the conflictual colonial encounter centrally pivots on race: "the first encounter with a white man oppresses [the Negro] with the whole weight of his blackness" (1986 [1952]:143). The lines of division are drawn - and drawn racially - with colonial oppression: "The Negro is in every sense of the word a victim of white civilisation - whether as [a] slave of a cultural imposition or, identifying with the white man, as [a] slave of himself" (Fanon, 1986 [1952]:192).

The preoccupation with the construction of contrary and mutually exclusive personality types structured by inferiority and dependence (Mannoni, 1990 [1952]:41) is what raised the hackles about Mannoni's project. Fanon's and Césaire's vehement rebuttals have decisively shaped the reception of Mannoni's book in postcolonial and cultural studies ever since.

To be sure, Mannoni's culturalist-psychological account of the colonial encounter was premised on and in turn generated expansive historical and political blind spots (Bloch, 1990:v, vi). In his 'New Foreword', Maurice Bloch points out that the book relies on extremely thin if not downright inaccurate ethnographic and historical evidence (Bloch, 1990:vi, xiv). Even for a psychological argument on Malagasy subjectivity, the basis remains 


\section{UNIVERSITY ON THE BORDER}

extremely tenuous, relying as it does on a limited knowledge of the language, scantiness of information (for instance the dream analysis based on school children's homework writing exercises), dubious sources (Caillet's earlier study attempting to psychologise the Malagasy, and his informant Dama Ntsoha's pursuit of a nationalist agenda of re-inventing 'tradition'), vast generalisations from observations of individual encounters to 'Malagasy culture' as a whole, and unjustifiable correlations with ethnographic findings from the African continent and Melanesia (Bloch, 1990:xiii).

Yet, Mannoni retains a historical perspective in relation to broadly differentiated modes of socio-cultural-psychic structuration. He notes the colonially engendered 'dependency complex' in particularly pronounced forms in the case of strong vertical ties corresponding to feudalism. This description, Mannoni finds, fits the Merina (1990 [1956]:41), who historically occupied the central highlands, and consolidated their polities into a kingdom towards the end of the eighteenth century. It is this stratum from which, at the time of Mannoni's writing about Madagascar, professionals were drawn (Bloch, 1990:x).

For the inhabitants of the coastal regions with historical links to the East African coast, on the other hand, 'dependency' does not emerge as a complex in the colonial encounter in quite the same way; in this case, it is inflected by horizontal, egalitarian networks (Bloch, 1990:ix; Mannoni, 1990 [1956]:66).

Thus, despite the fact that Mannoni's analysis of subjectivities in colonial conflict does not stand up to empirical-historical and ethnographic-methodological scrutiny, his differentiation of modes of psycho-social organisation is of some interest, which I would like to spell out further.

The so-called "dependency complex" of Mannoni's 'psychology of colonisation' in Madagascar is predicated on a pre-colonial social matrix characterised by a history of trans-oceanic Austronesian and African migration and settlement, internal conquest and slave-trading, sovereign dominions, feudal hierarchies, and central state formation which he clearly distinguishes from the social de-structuration in the French slave colonies. Under a system of rule implanted on a history of colonial slavery, Mannoni avers, "assimilation" is the more likely scenario, as "the personality of the native is first destroyed through uprooting, enslavement, and the collapse of the social structure" (1990 [1956]:27). This 
pertains to "the older colonies" that, as the translator explains, "remained after the eighteenth century and had been based on slavery - such as the Antilles and Réunion” (Mannoni, 1990 [1956]:27).

On the differentiation between conquest and colonialism, modes of subjugation and modes of subjection, which Mannoni elaborates here, Fanon is compelled to concede some ground. Not all forms of rule over 'the black man' are based on a history of slavery; not all subjects emerging 'out of slavery' are interpellated as acquiescent victims. Fanon quotes Gabriel d'Arboussier's critique of Sartre and négritude in this context:

When Sartre wrote, 'Simply by plunging into the depths of his memory as a former slave, the black man asserts that suffering is the lot of man and that it is no less undeserved on that account', did he take into consideration what that might mean for a Hova, ${ }^{4}$ a Moor, a Touareg, a Peul, or a Bantu of the Congo or the lvory Coast?

(Fanon, 1986 [1952]:172)

Fanon admits to the lack of historical and geopolitical differentiation in his analysis of colonial pathogeny. Writing on Martinique, he sees this pathogeny as "the consequence of [the] replacement of the repressed [African] spirit in the consciousness of the slave by an authority symbol representing the Master" (Fanon, 1986 [1952]:145). Fanon here approvingly cites René Ménil's Hegelianism in explaining the defensive reaction of a Negro intellectual. It is, he explains, his adherence to Hegelianism that drives his analysis, rather than his attention to the specific conditions of post-slavery societies of the Antilles. ${ }^{5}$

This interesting remark impels us to investigate the particular understandings of the Herrschaft - Knechtschaft ('Lordship - Bondage') relation in Hegel's Phänomenologie des Geistes (Phenomenology of Spirit, 1807) which, not surprisingly - given the differences between Mannoni's approach to the psychology of colonisation centred on feudalism and Fanon's approach to the psychology of colonisation centred on (post)slavery - pan out differently between the two analysts.

4 Pre-colonially, the Hova were free commoners, mostly merchants and farmers, erstwhile conquerors and slaveholders within the Merina kingdom, socially situated as the middle caste between Andriana nobility and Andevo slaves.

5 Fanon continues from Arbousier's critique and quotes: "The objection is valid. It applies to me as well. In the beginning I wanted to confine myself to the Antilles. But, regardless of consequences, the dialectic took the upper hand and I was compelled to see that the Antillean is first of all a Negro" (Fanon, 1986 [1952]:172). 


\section{UNIVERSITY ON THE BORDER}

Fanon, writing from the French reception of Hegel's Phänomenologie (mediated by Alexandre Kojève's Hegel lectures in the 1930s; Jean Hyppolite's translation of Phänomenologie between 1939 and 1942; and existentialism at the juncture with anti-colonial struggles) on the post-slavery society of Martinique, gives political content to Hegel's figure of the Knecht ('servant') as esclave ('slave'). In the section on 'The Negro and Hegel' in Chapter 7 ('The Negro and Recognition') of Black Skin White Masks, Fanon explicates Hegel's 'struggle for recognition' by which master and slave would, following Fanon's understanding of Hegel's script, come to self-consciousness through recognising themselves as mutually recognising each other (Fanon, 1986 [1952]:217). However, this struggle is foiled by the fact that in Martinican society, imprinted by a history of plantation slavery, the white master is not interested in mutual recognition - "what he wants from the slave is not recognition but work"; and the Negro slave does not "find[,] in his work the source of his liberation", but "wants to be like the master" (Fanon, 1986 [1952]:221).

Mannoni, writing from colonialism grafted onto feudal relations of personal dependency, does not explicitly refer to Hegel's figures in his book. At times, he is inclined to equate dependency with enslavement in terms similar to those of Fanon. ${ }^{6}$ But his interest in the psychic servitude of personal dependence would indicate a different understanding of the role of Hegel's figure - not as a relation of master and slave as expressed in chattel and plantation slavery, but as a relation of lord and bondsman in personal servitude. This understanding of the lord-bondsman relation reveals a reading of Hegel under the influence of Denis Diderot's Jacques le fataliste et son maître ('Jacques The Fatalist and His Master', written between 1765 and 1780 and published in 1796) - a parable about a master who is continuously in the process of losing his mastery, and indeed the plot, to his insolent valet. An outline of this figure appears in Mannoni's autocritique, in the reference to valets de chambre ('valets')

6 For example, Fanon (1990 [1956]:195). Similarly to Fanon's footnote on the thwarting of the "struggle for recognition" in the historical master-slave relation on Martinique, Mannoni describes colonial society in Madagascar in the following terms: "Colonial society [...] gives the dependent person nothing but his dependence. When confronted with a reality he has no feeling of liberation; his tools and his technical knowledge give him no sense of mastery - tools are simply an extension of the master's orders, technique just a set of rules to be obeyed; his hands are still the hands of a slave" (Mannoni, 1990:195). 
in the Italian commedia dell'arte, who intervene to mediate between their quarrelling masters (Mannoni, 1966:331). Here, the role of the psychologist and the role of the bondsman are assimilated to each other, in relation to the master.

In Hegel's Phänomenologie (1807), the figure of the valet appears at a moment and in a context - in the role as moral judgement in relation to action - that would give him a role different from Fanon's idea of Hegel's slave. Far from "wanting to be like the master", as Fanon had characterised the aspiration of the Martinican Negro slave, Hegel takes up Madame de Cornuel's witticism, "No man is a hero to his valet" - not

because the man is not a hero, but because the valet is a valet, whose dealings are with the man, not as a hero, but as one who eats, drinks, and wears clothes, in general, with his individual wants and fancies.

(Hegel, 1977 [1807]:404; Apter, 1999:86)

It is, paradoxically, Mannoni's construal of dependency, exemplified in the account of the exchanges with the young Merina tennis coach (Mannoni, 1990 [1956]:42-44), from which this masterful consciousness jokingly emerges on its terms, positing a relation of equality (Bloch, 1990:xvi-xviii).

This understanding of the significance of these exchanges, however, eluded Mannoni at the time, just as much as it eludes 'the white man' in the missed post-colonial encounter of which Mannoni writes in 'The Decolonisation of Myself'. It is at this point that 'race' and 'racism' come to feature thematically in Mannoni's analysis - to some extent strategically, to refute and refuse a "universalist solution, which has lost sight of the terms of the problem" (Mannoni, 1966:331), and even of the problem itself.

In wresting 'the terms of the problem' from a "universalist solution", a distinct problematic attains contours: Racism is not a matter of prejudices, illusions, fantasies or misunderstandings, and work to combat racism is not a matter of dispelling these: "the real problem is to be formulated not in terms of similarity but precisely in terms of the very difference between men since the important thing is to discover what men make of their differences, not to ignore them" (Mannoni, 1966:331). The task of the analyst is initially a negative one: not losing sight of the terms of the problem, which tend to be conjured away in liberal, humanist, universalist and moralising approaches to questions of 


\section{UNIVERSITY ON THE BORDER}

social justice, with which psychological explanations have variously been complicit (Mannoni, 1966:335) - including his own earlier ones, Mannoni admits (Mannoni, 1966:332). Placing the methods of psychoanalysis "within their proper limits" as Mannoni in his autocritique proposes to do, in contrast, entails a discursive limitation that presents the problem in new terms not as the colloquial 'social problem' but as an epistemologically salient 'problematic': what does it mean to "suggest psychological interpretations in such a field?” (Mannoni, 1966:329).

This question opens up an apparent contradiction: On the one hand, psychoanalysis is entrusted with the role of formulating "the terms of the deepest problems concerning human relationships", "[symbols] of what goes wrong in human relations" (Mannoni, 1966:333). "What is in question", Mannoni states quite apodictically, "is the coexistence of mankind, and not merely of the races" (Mannoni, 1966:334). On the other hand, Mannoni decisively renounces the universality of psychoanalysis - methodologically, by articulating it as a question of knowledge, and politically, by blocking the transitivity between the psychological and the political. It is, paradoxically, in the chapter titled 'The Unity of Mankind', that this renunciation finds expression: "It is not really necessary for us to find a psychological explanation for the facts of colonisation; what we need to know is why we perceive these facts in a distorted fashion" (Mannoni, 1990 [1956]:198), and what satisfactions such distortions offer.

Thus, the universalist claim on behalf of psychoanalysis - in terms of its reach, its subject, its object, its method, and its fulfilment - is suspended to allow 'the terms of the problem' to emerge, edging towards and urging 'The Decolonisation of Myself'. 


\section{REFERENCES}

Apter, E. 1999. Character Assassination. Racial Pathologies, Colonial Crimes - Fanon, Mannoni, Lacan, Paulhan. In: E. Apter. Continental Drift. From National Characters to Virtual Subjects. Chicago: University of Chicago Press.

Bergo, B. 2005. 'Roulez! Il n'y a rien à voir' Or, 'Seeing White': From Phenomenology to Psychoanalysis and Back. In: G. Yancy (ed.). White on White/Black on Black. Lanham: Rowman \& Littlefield Publishers.

Bloch, M. 1990. New Foreword. In: O. Mannoni (ed.). Prospero and Caliban: The Psychology of Colonization. P. Powesland (transl.). Ann Arbor, Michigan: University of Michigan Press.

Césaire, A. 1955. Discours sur le colonialisme ['Speech on Colonialism']. Paris: Présence Africaine.
Fanon, F. 1986 [1952]. Black Skin, White Masks. Charles Lam Markmann (transl.). London: Pluto Press.

Freud, S. 1963 [1909]. Letter to Oskar Pfister, 16.8.1909. In: H. Meng \& E.L. Freud (eds.). The Letters of Sigmund Freud and Oskar Pfister. E. Mosbacher (transl.). New York: Basic Books.

Hegel, G.W.F. 1977 [1807]. Phenomenology of Spirit. A.V. Miller (transl.). New York: Oxford University Press.

Mannoni, O. 1966. The Decolonisation of Myself. Race, VII(4):327-335. https://doi. org/10.1177/030639686600700401

Mannoni, O. 1990 [1950]. Prospero and Caliban: The Psychology of Colonization. Pamela Powesland (transl.). Ann Arbor, Michigan: University of Michigan Press. https:// doi.org/10.3998/mpub.9316 